\title{
ANALISIS PELAPISAN SOSIAL SERTA TINGKAT
PENDAPATAN DAN POLA PENGELUARAN RUMA TANGGA \\ USAHATANI BERDASARKAN PERILAKU SOSIAL BUDAYA ISLAMI
}

\author{
Musli Rosmali Sunandaka*)
}

\begin{abstract}
ABSTRAK
Penelitian ini bertujuan untuk mengetahui dan menganalisis pembentukan pelapisan sosial masyarakat pertanian muslim berdasarkan perilaku sosial budaya islami petani serta deskripsi tingkat pendapatan dan pola pengeluaran rumah tangga usahataninya. Penelitian dilaksanakan dengan menggunakan metode survey terhadap 240 rumah tangga usahatani sampel di Kabupaten Bandung dan Kabupaten Garut Provinsi Jawa Barat sebagai sentra produksi sayuran dataran tinggi. Hasil penelitian menunjukkan bahwa pelapisan sosial masyarakat pertanian muslim dengan teori pelapisan terbentuk menjadi dua lapisan, yaitu lapisan petani berperilaku sosial budaya islami yang lebih baik dan lapisan petani berperilaku sosial budaya islami yang kurang baik. Lapisan petani berperilaku sosial budaya islami yang lebih baik memiliki tingkat pendapatan rumah tangga usahatani yang lebih tinggi dan pola pengeluaran yang lebih rasional dan proporsional dibandingkan dengan lapisan petani berperilaku sosial budaya islami yang kurang baik.

Kata kunci : pelapisan sosial, polarisasi, perilaku sosial budaya islami, tingkat pendapatan, pola pengeluaran, rumah tangga usahatani.
\end{abstract}




\section{PENDAHULUAN}

Peran petani dalam usahatani terdapat tiga macam, yaitu sebagai juru tani, manajer, dan sebagai warga masyarakat yang terikat oleh kepercayaan atas agama yang dianutnya (Mosher, 1965 : 33-50). Penelitian tentang pembagian masyarakat pertanian secara dwibagi terhadap kedua peran pertama baik sebagai juru tani maupun sebagai manajer berdasarkan kriteria tertentu telah banyak dilakukan, namun terhadap peran yang ketiga yaitu scbagai warga masyarakat yang terikat oleh kepercayaan atas agama yang dianutnya masih terbatas sifatnya. Beberapa penelitian terdahulu antara lain sebagai berikut :

1) Rogers (1969: 130-133) berdasarkan tcori polarisasi (suatu kecenderungan perilaku manusia sebagai anggota masyarakat mengarah ke masing-masing kutub (poler)-nya, meskipun kebanyakan tidak sampai kepada ckstrim-ekstrim polemya menurut kriteria tertentu). Menurut kriteria saluran komunikasi yang digunakan dalam penerapan teknologi pertanian, ia membagi masyarakat pertanian Amerika menjadi dua golongan. Golongan pertama, yaitu masyarakat petani lokalit atau petani subsisten-tradisional (Columbian's peasant) yang lebih banyak menggunakan saluran komunikasi inter personal. Golongan dua, yaitu masyarakat petani kosmopolit atau petani komersial-modern (lowa's farmer) yang lebih banyak menggunakan saluran komunikasi mass media, karena memiliki tingkat literasi dan motivasi 
berprestasi yang lebih tinggi dibandingkan dengan masyarakat petani lokalit.

2) Soewardi (1976:95-97) berdasarkan teori polarisasi Rogers (1969) dengan kriteria tingkat respons terhadap penerapan teknologi produksi padi sawah (teknologi panca usaha), ia membagi masyarakat petani padi sawah di Jawa Barat menjadi dua lapisan. Lapisan pertama, yaitu petani lapisan atas sebanyak $34,5 \%$ atau sepertiga dari seluruh warga masyarakat petani, sedangkan sisanya duapertiga tergolong lapisan kedua, yaitu petani lapisan bawah. Petani lapisan atas memiliki respons yang lebih tinggi terhadap penerapan trknologi produksi dibandingkan dengan petani lapisan bawah. Selain itu petani lapisan atas memiliki tingkat pendapatan yang lcbih tinggi dan pola perbelanjaan yang lebih baik dibandingkan dengan petani lapisan bawah.

3) Arief (1990:272-275), pelapisan masyarakat petani padi sawah di jalur pantai utara Jawa Barat antara pola tanam spesialisasi padi monokultur dan pola tanam diversifikasi (padi-palawija-sayuran). Petani dengan pola tanam spesialisasi adalah petani subsisten/ petani lapisan bawah. Petani dengan pola tanam diversifikasi adalah petani komersial/petani lapisan atas. Petani dengan pola tanam spesialisasi sebagai petani subsisten/petani lapisan bawah menunjukkan perilaku keteguhan pegangannya terhadap jaminan rasa aman sangat kuat, namun sangat takut menghadapi risiko usahatani, sedangkan petani dengan pola tanam diversifikasi sebagai petani komersial/ petani lapisan 
atas menunjukkan perilaku keteguhan pegangannya terhadap jaminan rasa aman sangat longgar, namun sangat berani menghadapi risiko usahatani.

4) Natsir (1997: 239-241), membagi masyarakat muslim Jawa Barat menjadi dua golongan, yaitu muslim Qadariyah dan muslim Jabariyah. Muslim Qadariyah memiliki pola pemahaman terhadap ajaran Islam yang melihat kehidupam dunia dengan sikap positif dan optimis, sedangkan muslim Jabariyah yang melihat kehidupan dunia dengan sikap negatif dan pesimis. Bagi muslim Qadariyah berpendapat bahwa usaha dalam kegiatan ekonomi dipahami bukan hanya untuk memenuhi kebutuhan hidup semata, namun juga mengandung makna ibadat kepada Allah SWT. Kerja keras, hemat, rajin, jujur, dan berperhitungan dalam kegiatan ekonomi merupakan suatu keharusan menurut ajaran Islam yang memiliki makna ibadat. Bagi muslim Jabariyah berpendapat bahwa kerja keras, hemat, rajin, jujur dan berperhitungan dalam kegiatan ekonomi kurang memiliki makna ibadat untuk kepentingan ke akhiratan dan cenderung diabaikan selain dari itu muslim Qadariyah memiliki tingkah laku kewirausahaan yang lebih baik dibandingkan dengan muslim Jabariyah.

5) Sumaryana (2000: 207-208), pola konsumsi masyarakat negara berkembang yang meniru pola konsumsi negara maju yang ditemukan Nurkse pada tahun 1953, ditemukan pula pada masyarakat perdesaan dan perkotaan di Indonesia, karena terjadi efek demontrasi. Pendapatan merupakan faktor 
dominan yang mempengaruhi konsumsi rumah tangga usahatani yang meniru gaya hidup masyarakat kota, lahan dan modal, dorongan keberhasilan dan kemampuan manajerial serta penguasaan kesempatan kerja diluar usahatani secara bersama-sama tidak besar pengaruhnya (hanya $15 \%$ ) saja terhadap perkembangan ekonomi rumah tangga usahatani. Rumah tangga usahatani dengan pola konsumsi yang meniru gaya hidup masyarakat kota, disertai pemilikan lahan dan modal, dorongan keberhasilan dan kemampuan manajerial, kurang menunjukkan perkembangan ekonomi yang kurang berarti. Namun demikian rumah tangga usahatani yang memiliki lahan dan modal lebih besar, dorongan keberhasilan dan kemampuan manajerial lebih tinggi menunjukkan perkembangan ekonomi yang lebih baik dibandingkan dengan rumah tangga usahatani yang memiliki lahan dan modal lebih kecil, dorongan keberhasilan dan kemampuan manajerial yang lcbih rendah.

Penelitian atau kajian terdahulu tersebut di atas sangat mendukung penelitian penulis yang berlokasi di wilayah Priangan Jawa Barat, khususnya daerah Kabupaten Bandung dan Kabupaten Garut sebagai sentra produksi sayuran dataran tinggi serta mayoritas penduduknya beragama Islam. Tujuan penelitian untuk mengetahui dan menganalisis pembentukan pelapisan sosial secara dwibagi berdasarkan perilaku sosial budaya islami pada masyarakat pertanian dan pola pengeluarannya. Hasil penelitian akan berguna bagi pengambilan keputusan dalam menetapkan strategi kebijakan penyuluhan pertanian untuk 
mengubah perilaku petani ke arah bertani lebih baik, berusahatani lebih menguntungkan, hidup lebih sejahtera, dan bermasyarakat lebih baik (Padmowihardjo, $2001: 1.12$ ).

\section{METODE PENELITIAN}

\section{Pendekatan Analisis}

Unit analisis dalam penelitian ini adalah petani sebagai kepala keluarga rumah tangga usahatani sayuran dataran tinggi yang merupakan warga masyarakat pertanian. Metode penelitian yang digunakan adalah metode survey sampel. Teknik sampling berupa multi stage cluster random sampling. Dari dua Kabupaten sentra produksi sayuran dataran tinggi (Kabupaten Bandung dan Kabupaten Garut) terambil empat Kecamatan sampel, delapan Desa sampel.dari setiap Desa sampel diambil 30 rumah tangga usahatani secara acak sederhana, sehingga akhimya diperoleh 240 rumah tangga usahatani sampel $(\pi=240)$. Daerah penelitian dan ukuran unit-unit sampel dapat dilihat pada tabel sebagai berikut :

Tabel 1. Daerah Penelitian dan Ukuran Unit-unit Sampel

\begin{tabular}{|l|l|l|l|c|}
\hline No & $\begin{array}{c}\text { Daerah } \\
\text { Penelitian } \\
\text { (Finite } \\
\text { Population) }\end{array}$ & $\begin{array}{c}\text { Kecamatan } \\
\text { Sampel }\end{array}$ & $\begin{array}{c}\text { Desa } \\
\text { Sampel }\end{array}$ & $\begin{array}{c}\text { Rumah } \\
\text { Tangga } \\
\text { Usahatani } \\
\text { Sampel }\end{array}$ \\
\hline 1 & $\begin{array}{l}\text { Kabupaten } \\
\text { Bandung }\end{array}$ & Pangalengan & $\begin{array}{l}\text { Margamukti } \\
\text { Margamukti }\end{array}$ & $\mathbf{3 0}$ \\
& Pasir Jambu & Cisondari & $\mathbf{3 0}$ \\
\hline 2 & Kabupaten & Cikajang & Gibodas & $\mathbf{3 0}$ \\
\hline
\end{tabular}




\begin{tabular}{|l|l|c|l|c|}
\hline Garut & & Cikandang & 30 \\
& Cisurupan & $\begin{array}{l}\text { Cidatar } \\
\text { Cisero }\end{array}$ & 30 \\
& & $\mathbf{3}$ & $\mathbf{3 0}$ \\
\hline $\begin{array}{c}\text { Ukuran Unit } \\
\text { Sampel }\end{array}$ & 4 & & \\
\hline
\end{tabular}

Definisi dan operasional variabel yang diteliti adalah sebagai berikut :

1) Perilaku sosial budaya islami, yaitu perilaku petani berdasarkan pemahaman dan pengamalan nilai-nilai sosial budaya Islam seperti amanah, berorientasi ke masa depan, hemat, pantang menyerah, etos kerja, daya inovatif teknoligi, kemampuan bekerjasama, kemampuan manajerial. Daya tepa slira, dan motif berprestasi. Pengukuan tingkat pemahaman dan pengamalan nilai-nilai sosial budaya Islami tersebut menggunakan skaa ordinal bertaraf lima (berskor 5, 4, 3, 2, dan 1). Skor 5, 4, 3, 2, dan 1 menunjukan respon sangat tinggi, tinggi, cukup tinggi, rendah dan sangat rendah atau sangat baik, baik, cukup baik, kurang baik dan sangat kurang baik, perilaku sosial budaya islami ini merupakan pencerminan perilaku Nabi Muhammad s.a.w yang berlandaskan aqidah, syariah, akhlak dan mua'malat duniawiyah dalam kehidupan bermasyarakat (Ali Yafie, 1994 dalam Soewardi, $2001: 69)$.

2) Tingkat pendapatan rumah tangga usahatani, yaitu penerimaan usahatani dan usaha produktif lain secara bersama-sama akan menentukan tingkat pendapatan rumah 
tangga usahatani (Hardono, $2003: 2$ ). Penerimaan usahatani, dalam penelitian ini berupa hasil penjualan produksi sayuran dataran tinggi (bawang daun, bawang merah, buncis, cabe, kentang, kubis, lobak, petsai, tomat, dan wortel; BPS Provinsi Jawa Barat, 2004 :178 - 185) sesuai dengan harga yang berlaku, dikurangi biaya usahatani. Penerimaan usaha produktif lain, dalam penelitian ini berupa hasil usaha perdagangan dan usaha berburuh. Pengukuran tingkat pendapatan rumah tangga usahatani merupakan jumlah kumulatif dari penerimaan usahatani dan usaha produktif lainnya yang diukur dalam ribuan rupiah pertama.

3) Pola pengeluaran rumah tangga usaha tani, yaitu pendapatan rumah tangga usahatani dialokasikan pada berbagai pengeluaran (Handono, 2003 : 3). Berbagai pengeluaran dalam penelitian ini berupa pengeluaran konsumsi, tabungan dan investasi, zakat-infaq-sodakoh (ZIS), pajak dan kesejahteraan sosial kemasyarakatan, yang dihitung dalam ribuan rupiah per tahun beserta persentase nilai besaran pengeluarannya.

Untuk menganalisis pembentukan pelapisan sosial masyarakat pertanian muslim secara dwibagi berdasarkan kriteria perilaku sosial budaya islami menggunakan teori polarisasi Rogers (1969). Untuk menganalisis tingkat pendapatann rumah tangga usahatani pada dwibagi masyarakat pertanian muslim menggunakan konsep Handono (2003) serta uji beda dua rata-rata t-student test. Untuk menganalisis pola pengeluaran atau cara 
penggunaan pendapatan menggunakan konsep Handono (2003) dan dianalisis secara deskriptif.

\section{HASIL DAN PEMBAHASAN}

Analisis pembentukan pelapisan sosial masyarakat pertanian muslim

Pelapisan sosial masyarakat muslim secara dwibagi menggunakan teori polarisasi Rogers (1969). Polarisasi merupakan suatu garis kontinum yang menghubungkan kedua kutub (poler)-nya. Dari titik tengah garis kontinum itu akan terbagi menjadi dua lapisan yang mengarah ke masing-masing polernya, meskipun tidak sampai kepada ekstrim-ekstrim polernya.

Untuk menetukan titik tengah garis kontinum perilaku sosial budaya islami secara dwibagi pada masyarakat pertanian muslim, yaitu dengan menjumlahkan skor perilaku sosial budaya islami dari seluruh sampel rumah tangga usahatani $(\pi=240)$, diperoleh rata-rata jumlah skor perilaku $=35$, sebagai titik tengah. Titik tengah ini akan memilah dua lapisan petani berdasarkan perilaku sosial budaya islami. Jika skor perilaku $>35$, maka termasuk lapisan petani berperilaku sosial budaya islami yang lebih baik, dan sisanya jika skor perilaku $<35$, maka termasuk lapisan petani berperilaku sosial budaya islami yang kurang baik. Dari seluruh sampel $(\pi=240)$, maka diperoleh lapisan petani yang berperilaku sosial budaya islami yang lebih 
baik sebanyak 102 orang $\left(\pi_{1}=102\right)$ atau sebesar $42,50 \%$ dan sisanya lapisan petani berperilaku sosial budaya islami yang kurang baik sebanyak 138 orang $\left(\pi_{2}=138\right)$ atau sebesar $57,50 \%$. Komposisi pelapisan sosial masyarakat pertanian muslim secara dwibagi berdasarkan perilaku sosial budaya islami petani dapat dilihat pada gambar di bawah ini.

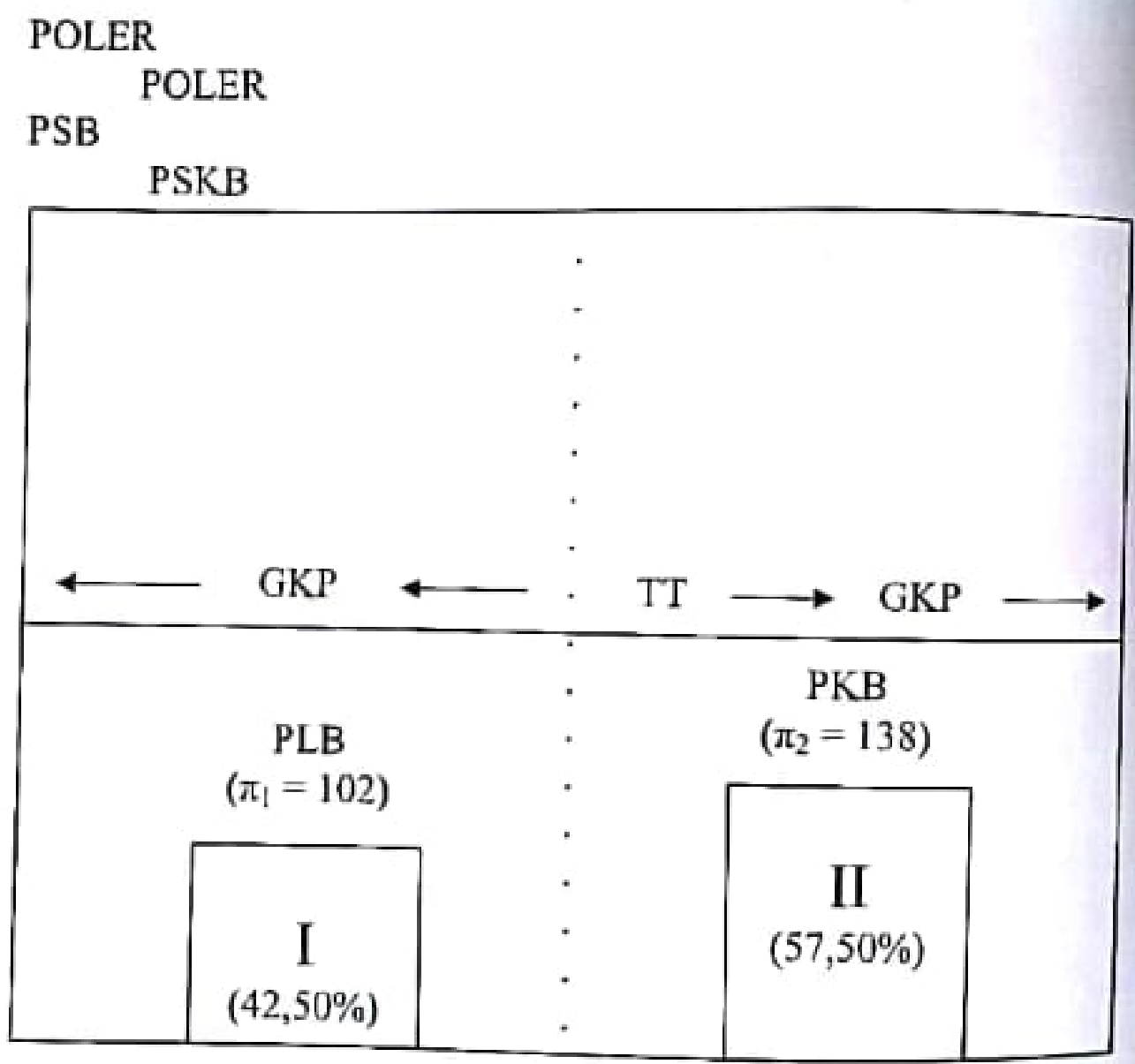

Gambar : Komposisi Pelapisan Sosial Masyarakat Pertanian Muslim

Ket. : PSB $=$ Perilaku Sangat Baik $;$ PSKB $=$ Perilaku Sangat Kurang Baik 
yang Lebih Baik

GKP $=$ Garis Kontinum Perilaku $;$ TT $=$ Titik Tengah

PLB $=$ Perilaku lebih Baik; PKB = Perilaku Kurang Baik

I = Lapisan Petani Berperilaku Sosial Budaya Islami

II = Lapisan Petani Berperilaku Sosial Budaya Islami yang Kurang Baik

Lapisan petani berperilaku sosial budaya islami yang lebih baik adalah identik dengan petani lapisan atas yang lebih responsif terhadap penerapan teknologi produksi (Soewardi, 1976); petani komersial yang berani menghadapi risiko usahatani (Airef, 1990); petani yang memiliki dorongan keberhasilan dan kemampuan manajerial lebih tinggi (Sumaryana, 2000); serta petani muslim-qadariyah yang bekerja keras, hemat, rajin, jujur, berperhitungan, dan memiliki sifat kewirausahaan yang tinggi (Natsir, 1997). Sedangkan lapisan petani berperilaku sosial budaya islami yang kurang baik menunjukkan karakteristik yang sebaliknya.

Jumlah lapisan petani berperilaku sosial budaya islami yang kurang baik sebagai petani lapisan bawah lebih besar daripada lapisan petani berperilaku sosial budaya islami yang lebih baik sebagai petani lapisan atas. Hal ini disebabkan oleh sebagian besar petani lapisan bawah masih berbudaya santai dengan sifat-sifat : (1) tidak ada orientasi ke masa depan, (2) tidak ada growth philosophy, (3) cepat menyerah, (4) retreatism, (5) inertia (Soewardi, 2001 : 128-129). 
Deskripsi Tingkat pendapatan dan Pola Pengeluaran Rumah Tangga Usahatani.

Tingkat pendapatan rumah tangga usaha tani merupakan jumlah kumulatif dari pendapatan usahatani sayuran sebagai pendapatan utama dan pendapatan usaha produktif lainnya (berdagang atau berburuh tani) sebagai pendapatan sampingan yang dihitung dalam ribuan rupiah per tahun. Pola pengeluaran atau pola perbelanjaan rumah tangga usahatani merupakan pengalokasian pendapatan untuk berbagai kebutuhan seperti konsumsi, tabungan atau investasi, ZIS, pajak dan kesejahteraan sosial kemasyarakatan (khitanan, perkawinan, kematian) yang dihitung dalam ribuan rupiah per tahun.

Rata-rata tingkat pendapatan dan pola pengeluaran rumah tangga usahatani pada kedua lapisan petani berperilaku sosial budaya islami yang lebih baik dan kurang baik dapat dilihat pada tabel sebagai berikut :

Tabel 2. Tingkat Pendapatan Dan Pola Pengeluaran Rumah Tangga Usahatani Lapisan Petani Berperilaku Sosial Budaya Islami yang Lebih Baik dan Lapisan

Petani Berperilaku Sosial Budaya Islami yang Kurang Baik.

\begin{tabular}{|l|c|c|}
\hline \multirow{7}{*}{ Indikator } & $\begin{array}{c}\text { Lapisan Petani } \\
\text { Berperilaku } \\
\text { Sosial Budaya islami } \\
\text { yang }\end{array}$ & $\begin{array}{c}\text { Lapisan Petani } \\
\text { Berperilaku } \\
\text { Sosial Budaya islami } \\
\text { yang Kurang } \\
\text { Baik }\left(\pi_{2}=138\right)\end{array}$ \\
\hline Tingkat Pendapatan & Rata-rata Rpr/ thn & Rata-rata Rpr/thn \\
\cline { 2 - 3 } Konsumsi & $18.284,794$ & $9.764,120$ \\
& $(100)$ & $(100)$ \\
& $10.056,674$ & $7.840,870$ \\
& $(55)$ & $(80,30)$ \\
\hline
\end{tabular}




\begin{tabular}{|l|c|c|}
\hline Tabungan \& Investasi & $6.357,300$ & $1.490,060$ \\
& $(34,76)$ & $(15,26)$ \\
ZIS & 767,620 & 165,300 \\
& $(4,20)$ & $(1,69)$ \\
Pajak dan Kesejahteraan & $1.103,200$ & 276,890 \\
Sosial kemasyarakatan & $(6,04)$ & $(2,75)$ \\
\hline
\end{tabular}

Catatan ; $\quad$ Rpr/thn = ribuan rupuan per tahun; $(\mathrm{I})=$ persen; ZIS = Zakat-Infaq-Sodakoh; Pajak = Pajak Bumi dan Bangunan;

Berdasarkan tabel 2, rata-rata pendapatan rumah tangga usahatani lapisan petani berperilaku sosial budaya islami yang lebih baik secara nominal memiliki tingkat pendapatan yang lebih tinggi $\mathrm{Rpr} / \mathrm{thn}=18.284,794$ dibandingkan dengan rata-rata pendapatan rumah tangga usahatani lapisan petani berperilaku sosial budaya islami yang kurang baik $(\mathrm{Rpr} / \mathrm{thn}=9.764,130)$. Terhadap hal ini kemudian lebih lanjut dilakukan uji beda dua rata-rata dengan uji statistik -student. Hasil pengujian statistik dapat dilihat pada tabel sebagai berikut

Tabel 3. Hasil Pengujian Statistik $t$-student terhadap Perbedaan RataRata Pendapatan Rumah Tanga Usahatani, Antar Lapisan Petani Berperilaku Sosial Budaya Islami yang Lebih Baik dan Kurang Baik.

\begin{tabular}{|l|c|c|c|c|}
\hline $\begin{array}{c}\text { Lapisan Petani } \\
\text { Berperilaku } \\
\text { Sosial Budaya Islami }\end{array}$ & $\begin{array}{c}\text { Rata-rata } \\
\text { Pendapatan } \\
(\text { Rpr/thn) }\end{array}$ & $\begin{array}{c}\text { Standar } \\
\text { Deviasi }\end{array}$ & T-hit & $\begin{array}{c}\text { Sig. } \\
(\boldsymbol{p} \text {-value })\end{array}$ \\
\hline $\begin{array}{l}\text { Yang lebih baik } \\
\left(\pi_{1}=102\right)\end{array}$ & $18.284,794$ & $9.324,673$ & 7,715 & 0.000 \\
\hline
\end{tabular}




\begin{tabular}{|l|l|l|l|l|}
\hline $\begin{array}{l}\text { Yang kurang baik } \\
\left(\pi_{2}=138\right)\end{array}$ & $9.764,120$ & $7.758,289$ & & \\
\hline
\end{tabular}

Catatan : $\quad \mathrm{t}_{\text {tab }} 0.05=1,645 ; \mathrm{t}_{\mathrm{tab}} 0.01=2,326$;

$\mathrm{Rpr} / \mathrm{thn}=$ Ribuan rupiah per tahun

Dari hasil pengujian statistik, diperoleh $t_{\text {hit }}=7,715>t_{\text {tab }}$ $0.001=2,325$, maka terdapat perbedaan yang sangat signifikan tingkat pendapatan antara lapisan petani berperilaku sosial budaya islami yang lebih baik dengan lapisan petani berperilaku sosial budaya islami yang kurang baik. Artinya tingkat pendapatan rumah tangga usahatani lapisan petani berperilaku sosial budaya islami yang lebih baik lebih tinggi dibandingkan dengan lapisan petani berperilaku sosial budaya islami yang kurang baik.

Gambaran tentang pola pengeluaran rumah tangga usahatani antara kedua lapisan petani berperilaku sosial budaya islami yang lebih baik dan yang kurang baik, secara relatif menunjukan proporsi pengaloksian pendapatan untuk konsumsi, tabungan dan investasi. ZIS, pajak dan kesejahteraan sosial kemasyarakatan pada rumah tangga usahatani lapisan petani berperilaku sosial budaya islami yang lebih baik adalah $55 \%$ untuk konsumsi (makanan dan bukan makanan), 34,76\% untuk tabungan dan inventasi, 4,20\% untuk ZIS, serta $6,04 \%$ untuk pajak (PBB) dan kesejahteraan sosial kemasyarakatan (khitanan, perkawinan, kematian). Lain halnya dengan proporsi pengalokasian penggunaan pendapatan pada rumah tangga usahatani lapisan petani berperilaku sosial budaya islami yang 
kurang baik yaitu $80,30 \%$ untuk konsumsi (makanan dan bukan makanan), 15,26\% untuk tabungan dan investasi $1,69 \%$ untuk ZIS, serta $2,75 \%$ untuk kesejahteraan sosial kemasyarakatan (khitanan, perkawinan, kematian).

Variasi pola pengeluaran rumah tangga usahatani antara kedua lapisan petani berperilaku sosial budaya islami yang lebih baik dan yang kurang baik menunjukkan karakteristik yang lebih berbeda satu dengan lainnya. Pola pengeluaran rumah tangga usahatani lapisan petani berperilaku sosial budaya islami yang lebih baik menunjukkan karakteristik sebagai berikut :

(1) Pola konsumsi bersifat pengendalian hawa nafsu, berorientasi ke pemenuhan kebutuhan hidup pokok yang cukup (need filfitment), hemat, dan efek demontrasinya bersifat produktif;

(2) Memiliki tingkat tabungan dan investasi yang lebih tinggi sebagai unsur pembentuk modal usaha dan kelangsungan usaha, serta lebih berorientasi jangka panjang; dan

(3) Memiliki tingkat kemampuan untuk berzakat, berinfaq, dan bersodakoh, serta memenuhi pajak (PBB) dan kesejahteraan sosial kemasyarakatan (khitanan, perkawinan, kematian) yang lebih tinggi, sehingga mampu melakukan transfer of wealth bagi masyarakat luas.

Lain halnya dengan pola pengeluaran rumah tangga usahatani lapisan petani berperilaku sosial budaya islami yang kurang baik menunjukkan karakteristik sebagai berikut : 
(1) Pola konsumsi bersifat pelampiasan hawa nafsu, berorientasi kepemenuhan kemauan hidup yang berlebih (want fulfitment), boros, dan efek demontrasinya berifat konsumtif;

(2) Memiliki tingkat tabungan dan investasi yang lebih rendah sebagai unsur pembentuk modal usaha dan kelangsungan usaha, serta berorientasi jangka pendek; dan

(3) Memiliki kemampuan untuk berzakat, berinfaq dan bersodakoh serta memenuhi pajak (PBB) dan kesejahteraan sosial kemasyarakatan (khitanan, perkawinan, kematian) yang lebih rendah, sehingga kurang mampu melakukan transfer of wealth bagi masyarakat luas.

Berdasarkan uraian tentang tingkat pendapatan dan pola pengeluaran rumah tangga usahatani antara kedua lapisan petani berperilaku sosial budaya islami yang lebih baik dan yang kurang baik, maka lapisan petani berperilaku sosial busaya islami yang lebih baik memiliki tingkat pendapatan yang lebih tinggi dan pola pengeluaran yang lebih baik dibandingkan dengan lapisan petani berperilaku sosial budaya islami yang kurang baik. 


\section{KESIMPULAN DAN IMPLIKASI KEBIJAKAN}

1. Pelapisan sosial masyarakat pertanian muslim berdasarkan perilaku sosial budaya islami petani terbentuk dua lapisan, yaitu lapisan petani berperilaku sosial budaya islami yang lebih baik sebesar $42,50 \%$ dan lapisan petani berperilaku sosial budaya islami yang kurang baik sebesar $57,50 \%$.

2. Lapisan petani berperilaku sosial budaya islami yang lebih baik memiliki tingkat pendapatan rumah tangga usahatani yang lebih tinggi dan pola pengeluaran yang lebih rasional dan proporsional dibandingkan dengan lapisan petani berperilaku sosial budaya islami yang kurang baik.

3. Program pembinaan dan pemberdayaan masyarakat pertanian muslim melalui kegiatan penyuluhan pertanian dan dakwah keagamaan yang selama ini berjalan masing-masing, perlu disinergikan secara terpadu dalam satu satuan sistem yang di fasilitasi olch pihak pemerintah daerah dan majelis ulama setempat. 


\section{DAFTAR PUSTAKA}

Arief, Burhan, 1990. Asas Rasa Aman dan Preferensi Risiko dalam Hubungan dengan Tumbuhnya Pola Usaha Diversifikasi di Daerah Irigasi Pantura Jawa Barat. Bandung : Disertasi Universitas Padjadjaran (Tidak Dipublikasikan).

BPS Provinsi Jawa Barat. 2004. Jawa Barat Dalam Angka 2003. Bandung : Badan

Pusat Statistik provinsi Jawa barat.

Hardono, Gatoet Sroe. 2003. Simulasi Dampak Perubahan Faktor-Faktor Ekonomi Terhadap Ketahanan Pangan Rumah Tangga Pertanian. Jurnal Agro Ekonomi Volume 21 Nomor 1, Mei 2003, Bogor : Pusat penelitian dan Pengembangan Sosial Ekonomi Pertanian. Badan Litbang Departemen Pertanian.

Mosher, A.T. 1965. Menggerakan dan Membangun Pertanian. Saduran Krisnandhi dan Bahrin Samad. Jakarta : CV Yasaguna.

Natsir, Nanat fatah. 1997. Pengaruh Pola Pemahaman Etika Kerja Islam Terhadap Tingkah Laku Kewirausahaan. Bandung : Disertasi Universitas Padjadjaran (Tidak Dipublikasikan)

Padmowihardjo, Soedijanto. 2001. Media Penyuluhan. Jakarta : Pusat Penerbitan Universitas Terbuka.

Rogers, Everett M.1969. Modernization Among Peasant. The Impact of Communication. New York : Halt, Rinehart and Winston, lnc.

Soewardi, Herman. 1976. Respons Masyarakat Desa Terhadap Modernisasi Produksi Pertanian. Suatu Kasus yang Terjadi di Jawa Barat. Yogyakarta Gadjah Mada University Press. 
Soewardi, Herman. 2001. Roda Berputar Dunia Bergulir. Kognisi Baru tentang Timbul Tenggelamnya Sivilisasi. Bandung : Penerbit Bakti mandiri.

Sumaryana, Asep. 2000. Pengaruh Pola Konsumsi Rumah Tangga Usahatani Meniru Gaya Kota Terhadap Perkembangan Ekonomi Petani. Bandung : Disertasi Program Pascasarjana Universitas Padjadjaran. (Tidak Dipublikasikan)

*) Musli Rosmali Sunandaka merupakan staf pemgajar Fakultas Pertanian Universitas Winaya Mukti 